\title{
Multiple Low Flow Vascular Malformation with Phleboliths - A Case Report
}

\author{
Saurabh Prakash, Veena Naik*, Jawahar Dhanavel \\ Orthodontics, Faculty of Dentistry, AIMST University Semeling, 08100 Bedong, Kedah Darul Aman, MALAYSIA.
}

\begin{abstract}
Objective: Venous malformation involving head and neck region is a rare entity. Hence, application of precise and leading diagnostic techniques, gives the accurate localization of the source vessel allowing for making treatment plan more satisfactory. Methods: We present a case of 30-year-old male patient with venous malformation involving head and neck region. We update the review of literature and also discuss the leading diagnostic aids for this rare entity disease so that iatrogenical accidents can be lessened. Case description: Our patient presented with solitary swelling in the left lower cheek region, left side of lateral border of tongue and $2-3$ small nodular swellings at the lateral border of the neck, lined obliquely over the sternocleidomastoid muscle. All the swellings were soft in consistency and non-tender, with no rise in temperature except for the swelling on the tongue. The lesion was confirmed by a radiograph which showed phleboliths. The ultrasound shows heterogeneously hypoechoic with multiple anechoic sinusoidal spaces (longitudinal plane) with mild vascularization and spectral analysis shows monophasic venous flow. This was later confirmed by direct puncture venography of the left cheek. Conclusion: The spectrum of vascular malformations is too vast; hence it becomes challenging to diagnose the lesion and fit it in the spectrum. These lesions are termed as intramuscular venous malformations based on clinical imaging and patho-
\end{abstract}

logic criteria and hence dentists must be aware of the clinical expression of these lesions in order to prevent iatrogenically related accidents and to minimize potential spontaneous crises for the patient. Having said that and keeping in mind the broad spectrum of vascular malformation, we present a clinically well diagnosed case of venous malformation, which illustrates phleboliths.

Key words: Venous malformations (VMs), Arteriovenous malformation (AVM), Phleboliths, Sclerotherapy, Venography and Hemangioma. Key message: Clinical manifestations of these lesions are extremely challenging. Experience in diagnosis and management of these lesions by most clinicians is limited. Therefore, additional diagnostic criterion that is simple and reliable and can be readily used to differentiate VMs

Correspondence :

Dr. Veena Naik, Faculty of Dentistry, AIMST Dental Center, AIMST University, Semeling, 08100 Bedong, Kedah Darul Aman, MALAYSIA.

Phone: +601126588376

Email: dr_veenasnaik@yahoo.co.in

DOI: 10.5530/jyp.2017.9.87

\section{INTRODUCTION}

Today venous malformations (VMs) pose one of the most difficult challenges in the practice of medicine. Venous malformations are part of a spectrum of vascular malformations commonly found in adults. William Hunter was the first to describe vascular anomalies in the mid- $18^{\text {th }}$ century in the context of iatrogenic formation of arterio-venous fistulas by phlebotomists. ${ }^{1}$ Venous malformations (VMs) occur in vessels that have low blood flow and are morphologically, histologically similar to veins. ${ }^{2}$ Early attempts at classification were based on the pathology of the lesions without considering underlying biologic behavior. However, Glowacki and Mulliken recommended that vascular lesions be divided into two major groups - hemangiomas and vascular malformations depending on histologic and clinical presentation. ${ }^{3}$ Years later, the Hamburg classification system adopted an embryologic perspective to further support the classification of vascular malformations. ${ }^{4}$ Which was later reclassified by Mulliken and Young and was adopted by the International Society for the Study of Vascular Anomalies (ISSVA) in 1996; and today it is the mainly used in classification with minimal changes to the original version. ${ }^{1}$

Arteriovenous malformation (AVM) is a congenital vascular malformation with a direct communication from arteries to veins with lack of normal capillary network. With its progression, AVM is capable of destroying normal tissues and can lead to complications, for instance severe disfigurement, unmanageable bleeding, ulceration, pain and cardiac volume overload. ${ }^{5}$ Initially lesions are recognized based on the prevailing vascular structure involved- arterial, venous, lymphatic, or capillary, considering arterio-venous shunting and also the combined vascular defects. The embryological background of the lesion is then considered for additional demarcation. ${ }^{6}$

\section{CASE REPORT}

A 30-year-old male patient reported with a complaint of pain in the lower right and left back tooth region since a week. Pain was insidious in onset, throbbing type, moderate in intensity, aggravated only while chewing food and relived after a while. He was moderately built and nourished with all the vital signs being normal. Extra oral examination revealed solitary swelling on the left cheek (Figure 1a) measuring about $5 \times 6 \mathrm{~cm}$, extending antero-posteriorly from body of mandible till $2 \mathrm{~mm}$ in front of the ear, superio-inferiorly from the line joining angle of mouth and tragus up to the lower border of mandible. Then there were $2-3$ small nodular swellings appreciated at the lateral border of the neck (Figure $1 \mathrm{~b}$ ), lined obliquely over the sternocleidomastoid muscle, each measuring about 2 to $3 \mathrm{~cm}$. Surface of all the swellings appeared to be smooth with prominent nerves and vessels giving the swellings a bluish tint. On palpation, the swelling were painless and soft, with no rise in temperature. A nodule was confirmed within the swelling at the lower border of mandible and the ones over the neck, indicating palpable lymph nodes, which were mobile, firm and non-tender. Intra orally the tongue was disfigured at the tip and on the left side causing Macroglossia

This is an open access article distributed under the terms of the Creative Commons Attribution-NonCommercial-ShareAlike 4.0 License, which allows others to remix, tweak, and build upon the work non-commercially, as long as the author is credited and the new creations are licensed under the identical terms. 


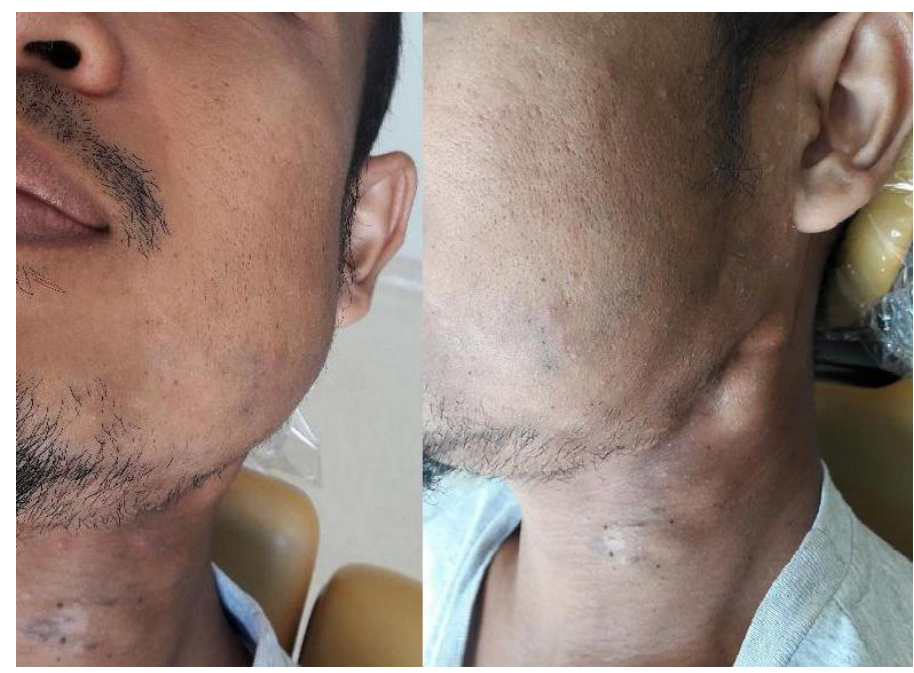

Figure 1a: Solitary mild bluish discolored swelling on the left cheek

Figure 1b: 2 - 3 small nodular swellings appreciated at the lateral border of the neck, lined obliquely over the sternocleidomastoid muscle.

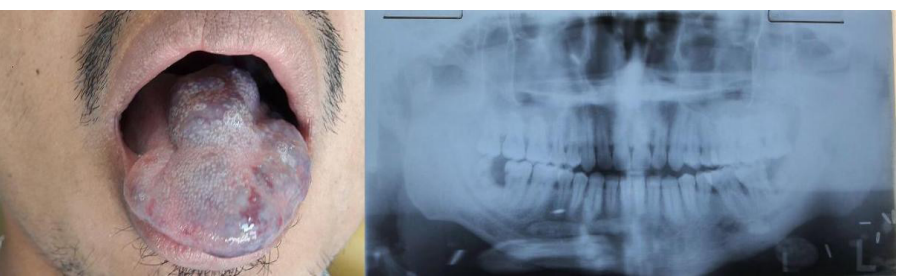

Figure 2a: tongue as well showed bluish swelling with disfigurement at the tip and on the left side leading to Macroglossia.

Figure 2b: Phleboliths noted at apex of 36 , one at the lower border of the mandible corresponding to 36,37 and around 4 to 5 calcifications seen in the pharyngeal space. Some needle like artifacts appreciated.

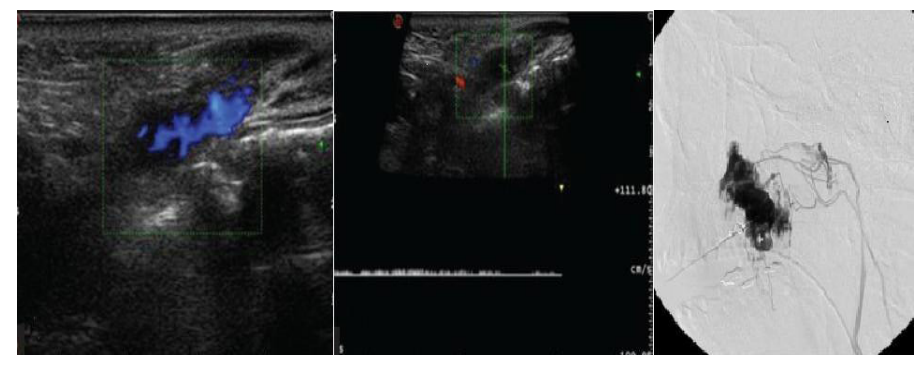

Figure 3a: At color-Doppler US image of cheek, the lesion appeared heterogeneously hypoechoic with multiple anechoic sinusoidal spaces (longitudinal plane) with mild vascularization.

Figure 3b: Monophasic venous flow was noted at spectral analysis.

Figure 3c: Direct puncture venography of the left cheek revealed pooling of contrast and draining into external jugular vein, showing opacification of venous malformation

and difficulty in speech (Figure 2a). The tongue as well showed a bluish discoloration, being soft to firm in consistency, non-tender and showed increase in temperature. Hard tissue examination revealed root stumps with 38 and 48, which were tender on percussion. We arrived at a provisional diagnosis of apical periodontitis in relation to 38 and 48 as per the patient's complaint. Based on the clinical appearance of the swellings of tongue, neck and cheek a provisional diagnosis of venous malformation was given, with a differential diagnosis of hemangioma and dermal melanocytic nevi.

We subjected the patient for OPG (orthopantomograph). His OPG (Figure $2 \mathrm{~b}$ ) revealed multiple calcifications. One calcification at the apical aspect of 36 overlying inferior alveolar canal and measuring $2 \times 3 \mathrm{~cm}$, roughly oval shaped. The other one at the lower border of the mandible corresponding to 36,37 , approximately of about $3 \times 4 \mathrm{~cm}$ and is rounded. Four to five calcifications seen in the pharyngeal space, each measuring $1 \times 1 \mathrm{~cm}$. all the calcifications show various amount of radiolucency within them. The calcifications suggestive of phleboliths, was supporting our clinical diagnosis. Later on, patient was subjected to color-Doppler US (ultrasound) of the cheek. The images revealed lesion with heterogeneously hypoechoic with multiple anechoic sinusoidal spaces (longitudinal plane) with mild vascularization (Figure 3a) and spectral analysis shows monophasic venous flow (Figure $3 \mathrm{~b}$ ), defects in the venous flow confirms our diagnosis of venous malformation. Direct puncture venography of the left cheek (Figure 3c) revealed pooling of contrast and draining into external jugular vein, showing opacification of venous malformation, which confirms our diagnosis. Patient was further referred to higher center for the appropriate treatment.

\section{DISCUSSION}

Vascular malformations are structural lesions resulting from errors of vascular morphogenesis. In other terms "Vascular malformation" is a generalized word used to portray a group of lesions, present at birth, formed by an anomaly of angiovascular or lymphovascular structures. ${ }^{7,8}$ In 1982, vascular anomalies (hemangioma) were grouped into two main major categories based on clinical, radiological and pathological features: "vascular tumors" and "vascular malformations. This was first dichotomised in this way by Mulliken and Glowacki in 1982, based on the histology, natural history and cellular activity of these lesions (Table 1). ${ }^{9}$ This classification was later adopted in 1996 by the International Society for the Study of Vascular Anomalies (ISSVA) at the 1996 meeting in Rome, and then the classification system was expanded at the 2014 ISSVA workshop in Melbourne (Table 2). ${ }^{10}$ These lesions often have components of multiple malformations, such as a mixed lymphatico-venous malformation, further adding to the confusion with respect to proper nomenclature. ${ }^{11-24}$

\section{Low-Flow Venous Malformations}

Venous malformations are part of a spectrum of vascular malformations commonly found in adults. ${ }^{12}$ Venous malformation is defined as malformations comprised of slow-flowing, abnormal dilated veins, and venous network. ${ }^{13}$ Clinically, these lesions appear as a soft, compressible and blue mass, typically present within the cutaneous tissues of the face, trunk, and limbs, although involvement of the viscera and bones has also been described, as seen in the present case. It is noted that two thirds of all vascular malformations are venous predominant (Table 3 ).

Experienced clinician can arrive at the diagnosis based on clinical history (presence at birth, growth during life, triggers such as puberty or trauma, and family history) and examination (Table 3). Important clinical clues are color (variations of pink, red, blue and purple), aspect (flat, raised, homogeneous, patchy, hyperkeratotic and ulcerated), localization, size, distribution (uni- or multifocal), palpation (hard, firm, compressible, and presence of a thrill), temperature (warm or normal), painfulness (spontaneous or provoking factors) and auscultation (bruit). ${ }^{14}$

\section{Epidemiology}

VMs are the most common type of vascular malformation, affecting $1 \%$ to $4 \%$ of individuals. The overall incidence of VM is about one in $10000 .^{1}$ Although it is felt that there is no gender predisposition, one series did find a female preponderance. ${ }^{15}$ The oral cavity (59\%) and nasal cavity 
Table 1: Differentiation of vascular tumours and malformations

\begin{tabular}{|c|c|c|c|c|}
\hline \multicolumn{5}{|c|}{ Vascular tumours } \\
\hline \multirow[t]{2}{*}{ Differentiation } & \multirow[t]{2}{*}{ Infantile haemangioma } & \multirow[t]{2}{*}{ Congenital haemangioma } & Kaposiform & \multirow[t]{2}{*}{ Vascular malformations } \\
\hline & & & $\begin{array}{l}\text { hemangioendothelioma; tufted } \\
\text { angioma }\end{array}$ & \\
\hline \multirow[t]{2}{*}{ Presentation } & \multirow[t]{2}{*}{ Absent or small at birth } & Present at birth & \multirow[t]{2}{*}{ Present before age of 5 years } & \multirow[t]{2}{*}{ Present at birth } \\
\hline & & —commonly large & & \\
\hline \multirow[t]{2}{*}{ Growth } & \multirow[t]{2}{*}{ Rapid growth during infancy } & \multirow[t]{2}{*}{ No growth } & Slow growth during childhood; & \multirow{2}{*}{$\begin{array}{l}\text { Proportional to growth of } \\
\text { child }\end{array}$} \\
\hline & & & $\begin{array}{l}\text { hemangioendothelioma can be locally } \\
\text { aggressive }\end{array}$ & \\
\hline Involution & $\begin{array}{l}\text { Involution through childhood } \\
\text { ( } 90 \% \text { by } 9 \text { years) }\end{array}$ & $\begin{array}{l}\text { Rapid involution (RICH) } \\
\text { within first year of life; or non- } \\
\text { involuting (NICH) }\end{array}$ & No involution & No spontaneous regression \\
\hline Lesion & Solid lesion & Solid lesion & Solid lesion & $\begin{array}{l}\text { Lesion comprises dysplastic } \\
\text { vessels, spaces or channels }\end{array}$ \\
\hline
\end{tabular}

RICH- rapidly involuting congenital haemangioma;

NICH- non-involuting congenital haemangioma

Table 2: ISSVA classification for vascular anomalies (2014).

\begin{tabular}{ccccc}
\hline \multirow{2}{*}{ Vascular tumors } & \multicolumn{3}{c}{ Vascular anomalies } \\
\hline \multirow{2}{*}{$\begin{array}{c}\text { Simple } \\
\text { Benign }\end{array}$} & Combined & $\begin{array}{c}\text { Of major named } \\
\text { vessels }\end{array}$ & $\begin{array}{c}\text { Associated with } \\
\text { other anomalies }\end{array}$ \\
\cline { 2 - 4 } $\begin{array}{c}\text { Locally aggressive or } \\
\text { borderline }\end{array}$ & Vymphatic malformations & CVnous malformations & LVM, CLVM & Check the list below \\
Arteriovenous malformations & CAVM & \\
Malignant & CLAVM & \\
\hline
\end{tabular}

Capillary venous malformation (CVM)

Capillary lymphatic malformation (CLM)

Lymphatic venous malformation (LVM)

Capillary lymphatic venous (CLVM)

Capillary arteriovenous malformation (CAVM)

Capillary lymphatic arteriovenous malformation (CLAVM)

\begin{tabular}{|c|c|}
\hline \multicolumn{2}{|c|}{ Vascular malformations associated with other anomalies } \\
\hline Klippel-Trenaunay syndrome & $\mathrm{CM}+\mathrm{VM}+/-\mathrm{LM}+$ limb growth \\
\hline Parkes Weber syndrome & $\mathrm{CM}+\mathrm{AVF}+\mathrm{Limb}$ growth \\
\hline Servelle Martorell syndrome & Limb VM + Bone undergrowth \\
\hline Struge Weber syndrome & $\begin{array}{c}\text { Facial+leptomeningeal } \mathrm{CM}+\text { eye anomalies }+/ \text { - bone and /or soft tissue } \\
\text { overgrowth }\end{array}$ \\
\hline \multicolumn{2}{|c|}{ Limb CM +congenital non-progressive limb hypertrophy } \\
\hline Maffucci syndrome & $\mathrm{VM}+/$ - spindle cell hemangioma + enchondroma \\
\hline Macrocephaly & $\mathrm{CM}$ \\
\hline Microcephaly & $\mathrm{CM}$ \\
\hline Cloves syndrome & $\mathrm{LM}+\mathrm{VM}+\mathrm{CM}+/-\mathrm{AVM}+$ lipomatous overgrowth \\
\hline Proteus syndrome & $\mathrm{CM}, \mathrm{VM}$ and/or LM + asymmetrical somatic overgrowth \\
\hline Bannayan-Riley-Ruvalcaba & $\mathrm{AVM}+\mathrm{VM}+$ macrocephaly, lipomatous overgrowth \\
\hline
\end{tabular}




\begin{tabular}{|c|c|c|c|c|c|}
\hline Venous Anomalies & Genetic & $\begin{array}{l}\text { \#,localization, color } \\
\text { and palpation }\end{array}$ & Other features & Histology & Management \\
\hline \multicolumn{6}{|c|}{ Simple } \\
\hline Unifocal sporadic & $\begin{array}{c}\text { Somatic activation } \\
\text { TIE2 } \\
(49 \%)\end{array}$ & $\begin{array}{c}\text { solitary, all tissues \& } \\
\text { internal organs, normal } \\
\text { to bluish color, } \\
\text { compressible, } \\
\text { phleboliths }\end{array}$ & & & \\
\hline Multifocal sporadic & $\begin{array}{l}\text { somatic activation } \\
\text { TIE2 }\end{array}$ & $\begin{array}{l}\text { multifocal, mucosal, } \\
\text { cutaneous \& muscular, } \\
\text { normal to bluish color, } \\
\text { less compressible }\end{array}$ & $\begin{array}{c}\text { pain at awakening \& } \\
\text { effort, } \\
\text { elevated D-dimer } \\
\text { level, local }\end{array}$ & $\begin{array}{l}\text { enlarged venous } \\
\text { channels, flattened layer } \\
\text { of endothelial cells, } \\
\text { sparse smooth }\end{array}$ & $\begin{array}{l}\text { elastic compression, } \\
\text { NSAI, LMWH, } \\
\text { sclerotherapy, } \\
\text { surgery }\end{array}$ \\
\hline VMCM & $\begin{array}{c}\text { germinal activation } \\
\text { TIE2 }\end{array}$ & $\begin{array}{l}\text { multifocal, mucosal \& } \\
\text { cutaneous, bluish } \\
\text { color, less compressible }\end{array}$ & $\begin{array}{l}\text { thrombosis } \\
\text { (phlebolith), no } \\
\text { pulmonary embolism }\end{array}$ & muscle cells & 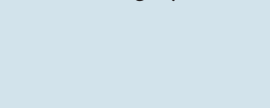 \\
\hline Glomuvenous & $\begin{array}{l}\text { loss of function } \\
\text { Glomulin }\end{array}$ & $\begin{array}{c}\text { multifocal, cutaneous, } \\
\text { bluish to purple color, } \\
\text { nodular or plaquelike, } \\
\text { not compressible,no } \\
\text { phlebolith }\end{array}$ & $\begin{array}{l}\text { pain at compression, } \\
\text { normal D-dimer level }\end{array}$ & $\begin{array}{c}\text { enlarged venous } \\
\text { channels \& } \\
\text { undifferentiated smooth } \\
\text { muscle cells = "glomus } \\
\text { cells" }\end{array}$ & $\begin{array}{c}\text { no compression, NSAI, } \\
\text { surgery, rarely } \\
\text { sclerotherapy }\end{array}$ \\
\hline \multicolumn{6}{|c|}{ Combined } \\
\hline Capillarovenous & Unknown & $\begin{array}{l}\text { solitary, cutaneous, } \\
\text { subcutaneous, red to } \\
\text { bluish-purple color, } \\
\text { capillary malformation } \\
\text { overlying venous } \\
\text { malformation, less } \\
\text { compressible }\end{array}$ & & & \\
\hline \multirow[t]{2}{*}{ Lymphaticovenous } & unknown & $\begin{array}{l}\text { capillary malformation } \\
\& \text { distant multifocal } \\
\text { venous malformations, } \\
\text { less compressible }\end{array}$ & $\begin{array}{c}\text { pain at awakening \& } \\
\text { effort, } \\
\text { elevated D-dimer } \\
\text { level }\end{array}$ & $\begin{array}{c}\text { increased number of } \\
\text { dilated capillaries }+ \\
\text { dilated venous-like } \\
\text { channels with relative } \\
\text { lack of smooth muscle } \\
\text { cells }\end{array}$ & \\
\hline & & $\begin{array}{l}\text { solitary, bluish-purple } \\
\text { color, lymphatic } \\
\text { dermal vesicles \& } \\
\text { subcutaneous venous } \\
\text { malformation, not } \\
\text { compressible }\end{array}$ & $\begin{array}{l}\text { lymphatic oozing \& } \\
\text { infection }\end{array}$ & $\begin{array}{l}\text { lymphatic dermal } \\
\text { vesicles + dilated } \\
\text { venous-like channels } \\
\text { with relative lack } \\
\text { of smooth muscle cells }\end{array}$ & $\begin{array}{c}\text { laser, elastic } \\
\text { compression, NSAI, } \\
\text { LMWH, } \\
\text { sclerotherapy, surgery }\end{array}$ \\
\hline
\end{tabular}

(35\%) were the most common locations. Tongue and lips are sites for the lesion involving oral cavity, and nasal septum in the nasal cavity. ${ }^{16,17}$

\section{Etiology}

There was no evidence that drugs or medications taken during pregnancy, or environmental exposures that may have occurred during that time can cause venous malformations. $100 \%$ are present at birth, although not all are clinically apparent. Abnormal sprouting or branching during embryonic development can result in venous malformations. ${ }^{18}$

\section{Investigation}

Patient's history and physical examination normally provides sufficient information to make the diagnosis. Conventional radiography generally reveals a soft-tissue mass with an occasional phleboliths and seldom adjacent skeletal anomalies. ${ }^{12}$ Lesions that are in the head / neck region enlarge when the patient forces air from the lungs with the vocal cords held closed (Valsalva maneuver). They show a tendency to thrombosis, leading to phleboliths, which are pathognomonic of VM and are diagnostic on imaging studies. Phleboliths are intralesional calcifications formed as a result of venous stasis and inflammation. ${ }^{14}$
Ultrasound (US) is often the initial investigation to evaluate vascular malformations and it may characterize and define the extent of more superficial lesions. ${ }^{19}$

MRI is most useful for defining the extent of the disease. Angiography is also a useful modality for defining extent of disease, especially when identifying deep or small VMs, such as intracranial sinus pericranii or gastrointestinal VM. ${ }^{12-20}$

In the present case, phleboliths were seen on plain radiography and were suggestive of vascular anomaly with slow flow rate. Whereas, by direct phlebography the lesion was seen draining the regional vein. These investigation features were suggestive of venous malformation.

\section{Treatment}

Low flow venous malformations could be treated by compression, surgical excision or sclerosis. Treatment should be reserved for symptomatic or cosmetically disfiguring malformations. Zheng et al. reported that laser therapy is recommended for superficial venous malformations ${ }^{17}$. A Sclerosing agent, which comprises the main type of treatment, includes STS (sodium tetradecyl sulfate), polidocanol, and absolute alcohol. ${ }^{21}$ Hyodoh $\mathrm{H}$ et al reported excellent results with sclerotherapy in 53\%-100\% 
patients. ${ }^{22}$ According to Lee $\mathrm{BB}$ et al, success rates using absolute alcohol have been reported in up to $95 \%$ with no evidence of recurrence. ${ }^{23,24}$

Results

In comparison to hemangiomas, vascular malformations diagnosed at birth shows no signs of involution with age and might expand close to puberty. In our case swelling was seen later in life, which was bluish in color and no signs of palpation or rise in temperature, leads to the diagnosis of venous malformation. Further the investigations show positive results, the OPG shows phleboliths, which is again a pathognomonic of the lesion. The ultra sound with monophasic venous flow (Figure 3b), defects in the venous flow and direct venography confirms our diagnosis of venous malformation.

\section{Conclusion}

The approach to the described entities requires an organized multidisciplinary team effort. Whereas a significant role is played by diagnostic imaging in the proper diagnosis and a combined interventional radiologic and surgical treatment method is showing promising results.

\section{CONFLICT OF INTEREST}

No Conflict of Interest Declared.

\section{ABBREVIATIONS USED}

VMs: Venous malformations; AVM: Arteriovenous malformation; OPG: orthopantomograph; US: ultrasound; ISSVA: International Society for the Study of Vascular Anomalies; STS: Sodium tetradecyl sulfate; LMWH: Low molecular weight heparin.

\section{REFERENCES}

1. LakkasettyYT, Malik S, Shetty A, Nakhaei K. Multiple vascular malformations in head and neck - Rare case report. J Oral Maxillofac Pathol. 2014;18(1):137-42. https:// doi.org/10.4103/0973-029X.131944 ; PMid:24959056 PMCid:PMC4065433.

2. Yakes WF. Diagnosis and management of low flow venolymphatic vascular malformation. Ces Radiol. 2008;62(131):e45.

3. Kelly DE, Terry BC, Small EW. Arteriovenous malformation of the mandible: report of case. J Oral Surg. 1977; 3:387-93.

4. John L Nosher, Philip G Murillo, Mark Liszewski, Vyacheslav Gendel, and Christopher E Gribbin. Vascular anomalies: A pictorial review of nomenclature, diagnosis and treatment. World J Radiol. 2014;28;6(9):677-92.

5. Pekkola J, Lappalainen $\mathrm{K}$, et al. Head and neck arteriovenous malformations: Results of ethanol sclerotherapy. AJNR Am J Neuroradiol. 2013;34(1):198-204. https://doi.org/10.3174/ajnr.A3180; PMid:22766677.

6. Lee BB, Laredo J, Lee TS, Huh S, Neville R. Terminology and classification of congenital vascular malformations. Phlebology. 2007;22(6):249-52 https://doi.org/10.1258/026835507782655236 : https://doi.org/10.1258/02683 5507782655245 : https://doi.org/10.1258/026835507782655182 : https://doi. org/10.1258/026835507782655272; PMid:18274331
7. Katherine Kula, George Blakey, J. Timothy Wright, Bill C. Terry. High-flow vascular malformations: literature review and case report. Pediatr Dent. 1996;18:4:322-7. PMid:8857662.

8. F. Martines and V. Immordino, "Arteriovenous malformation of the base of tongue in pregnancy: case report," Acta Otorhinolaryngol Ital. 2009;29(5):274-8 PMid:20162030 PMCid:PMC2821122.

9. Mahady K, Thust S, Berkeley R, Stuart S, Barnacle A, et al. Vascular anomalies of the head and neck in children. Quant Imaging Med Surg. 2015;5(6):886-97. PMid:26807370 PMCid:PMC4700245.

10. Dasgupta R, Fishman SJ. ISSVA classification. Semin Pediatr Surg. 2014:23:158-61 https://doi.org/10.1053/j.sempedsurg.2014.06.016; PMid:25241091.

11. Cox JA, Bartlett E, Lee El. Vascular Malformations: A Review. Semin Plast Surg. 2014;28(2):58-63. https://doi.org/10.1055/s-0034-1376263; PMid:25045330 PMCid:PMC4078214

12. Waldman EH, Goldenberg D, Califano J, Sciubba JJ, Tunkel DE. Venous malformation of the sternomastoid muscle: A case report and review. Otolaryngol Head Neck Surg. 2004:131(2):P310. https://doi.org/10.1016/j.otohns.2004.06.691.

13. Dubois J, Soulez G, et al. Soft-tissue venous malformations in adult patients: Imaging and therapeutic issues. Radiographics. 2001;21(6):1519-31. https://doi. org/10.1148/radiographics.21.6.g01nv031519; PMid:11706222.

14. Dompmartin A, Vikkula M, Boon LM. Venous Malformation: update on etiopathogenesis, diagnosis \& management. Phlebol. 2010;25(5):224-35. https:// doi.org/10.1258/phleb.2009.009041 ; PMid:20870869 PMCid:PMC3132084.

15. Mazoyer E, Enjolras $\mathrm{O}$, et al. Coagulation disorders in patients with venous malformation of the limbs and trunk: a case series of 118 patients. Arch Dermatol. 2008;144:861-7. https://doi.org/10.1001/archderm.144.7.861; PMid:18645137.

16. Stapf C, Mohr JP, et al. Epidemiology and natural history of arteriovenous malformations. Neurosurg Focus. 2001;11(5):e1. https://doi.org/10.3171/ foc.2001.11.5.2; PMid:16466233.

17. Kobayashi K, Nakao K, et al. Vascular malformations of the head and neck. Auris Nasus Larynx. 2013;40;89-92. https://doi.org/10.1016/j.anl.2012.02.002; PMid:22534179.

18. Boon LM, Mulliken JB, Vikkula M, et al. Assignment of a locus for dominantly inherited venous malformations to chromosome 9p. Hum Mol Genet. 1994;3(9):1583-7. https://doi.org/10.1093/hmg/3.9.1583 ; PMid:7833915.

19. Trop I, Dubois J, et al. Soft-tissue venous malformations in pediatric and young adult patients: diagnosis with Doppler US. Radiology. 1999;212(3):841-5. https:// doi.org/10.1148/radiology.212.3.r99au11841; PMid:10478255.

20. Yonetsu K, Nakayama E, Miwa K, Tanaka T, Araki K, Kanda S, et al. Magnetic resonance imaging of oral and maxillofacial angiomas. Oral Surg Oral Med Ora Pathol. 1993;76(6):783-9. https://doi.org/10.1016/0030-4220(93)90052-6.

21. Candamourty R, Venkatachalam S, Babu MRR, Reddy VK. Low flow vascular malformation of the buccal mucosa treated conservatively by sclerotherapy (3\% sodium tetradecyl sulfate). J Nat Sci Biol Med. 2012;3(2):195-8. https://doi. org/10.4103/0976-9668.101921. PMid:23225986 PMCid:PMC3510918

22. Hyodoh H, Hori M, Akiba H, Tamakawa M, Hyodoh K, Hareyama M. Peripheral vascular malformations: imaging, treatment approaches, and therapeutic issues. Radiographics. 2005;25(1):S159-71. https://doi.org/10.1148/ rg.25si055509; PMid:16227489.

23. Lee BB, DoYS, Byun HS, et al. Advanced management of venous malformation with ethanol sclerotherapy: mid-term results. J Vasc Surg. 2003;37(3):533-8 https://doi.org/10.1067/mva.2003.91; PMid:12618688.

24. Mulliken JB, Glowacki J. Hemangiomas and vascular malformations in infants and children: A classification based on endothelial characteristics. Plast Reconstr Surg. 1982;69(3):412-22. https://doi.org/10.1097/00006534198203000-00002. 